\title{
(Dis)sensos e lógicas das famílias em um centro judiciário de solução de conflitos e cidadania
}

\author{
CAMILLA FELIX BARBOSA DE OLIVEIRA \\ UNIVERSIDADE FEDERAL DO AMAZONAS (UFAM), MANAUS/AM, BRASIL \\ HTTPS://ORCID.ORG/OOO0-0002-9I3I-0265
}

RAQUEL WIGGERS

UNIVERSIDADE FEDERAL DO AMAZONAS (UFAM), MANAUS/AM, BRASIL HTTPS://ORCID.ORG/OOOO-0OOI-9900-8595

\section{Introdução}

Este artigo traz um recorte de pesquisa ${ }^{1}$ desenvolvida em Manaus, no Amazonas, acerca das relações entre as famílias e a justiça, na qual buscou-se evidenciar as construções discursivas e as lógicas locais das famílias que demandam os serviços do chamado Centro Judiciário de Solução de Conflitos e Cidadania (Cejusc). Tendo por base epistemológica a análise foucaultiana acerca da produção de verdades através de discursos e dispositivos que fazem emergir subjetividades, buscamos neste texto considerar o conjunto heterogêneo de práticas, saberes e tecnologias presentes no Judiciário que possibilitaram a construção de lógicas, enunciados, sujeitos e realidades específicas.

Ao tecer uma análise sobre os chamados "métodos alternativos ou adequados de resolução de conflitos" - dentre os quais destacamos neste texto as Oficinas de Divórcio e Parentalidade -, notamos a emergência de discursos que enaltecem uma justiça cada vez mais sensível às problemáticas subjetivas, o que nos levou a questionar em que medida tal movimento concebido como "humanização da justiça" poderia, por outro ângulo, evidenciar o fenômeno que denominamos de "judicialização do humano"

1 O artigo é resultado da pesquisa doutoral (Oliveira, 2020) realizada pela primeira autora e supervisionada pela segunda junto ao Programa de Pós-Graduação em Antropologia Social (PPGAS), vinculado à Universidade Federal do Amazonas (UFAM). Apesar de não ter contado com financiamento por meio de bolsa, agradecemos ao PPGAS/UFAM e à Capes pelo apoio à pesquisa, bem como pela indicação da tese ao prêmio Capes de Tese 2021. 
(Oliveira \& Brito, 2016). Desde então, observamos como a ideia de uma justiça humanizada está atrelada às formas de gestão de conflitos, relacionamentos, afetos e comportamentos por parte do Judiciário, o qual vem operando com o biopoder (Foucault, 2005) e alargando sua intervenção por meio de biopolíticas direcionadas a cada vez mais aspectos da vida e das relações sociais, em especial na esfera das famílias. Ademais, tal modalidade de poder afeta diretamente as subjetividades, produzindo determinadas modalidades de ser e viver, normatizando atitudes, falas e emoções que os sujeitos passam a incorporar como escolhas individuais ou características pessoais.

Em meio a diferentes estudos antropológicos e etnografias sobre famílias e parentesco, buscamos desenvolver uma abordagem que problematiza os sentidos, os valores e as práticas sobre as famílias produzidos em determinados contextos, tal como sugerido por Schuch (2012), e que contribua para sua "desnaturalização" (Sarti, 1992:71), abarcando seu caráter social e cultural. No que tange ao âmbito jurídico, concordamos com Fonseca (2011) que a ação judicial, mais do que resolver disputas, molda subjetividades, indicando que o efeito dos processos não se restringe à mera constatação dos fatos, mas ressoa nas atitudes dos sujeitos. Ao dialogarmos, ainda, com outros autores que concebem a família enquanto "categoria social" (Schuch, 2012:11; Sarti, 1992) - tendo em vista que ela não se origina na unidade biológica, sendo anterior à reprodução - e a parentalidade como "dispositivo" (Neyrand, 2013:25) de suporte e controle social, voltamos nosso olhar para o conjunto de enunciados, sensos e lógicas sociais sobre os conflitos familiares que caracterizam as políticas conciliatórias desenvolvidas no Cejusc, com especial interesse pelo enquadramento judicializante e psicologizante, haja vista que a judicialização dos conflitos familiares provoca "rearranjos na sua constelação de afetos" (Fonseca, 2011:15).

Por judicialização referimo-nos aqui a um duplo movimento: (I) no âmbito jurídico e legislativo, por meio da ampliação de leis, medidas, políticas e tecnologias destinadas à gestão dos conflitos familiares e das relações sociais, promovendo uma espécie de regulação normativa do viver (Oliveira \& Brito, 2016; Rifiotis, 2007; 2014); (II) e no âmbito privado e social, por meio da incorporação da semântica do Direito e da racionalidade jurídica nas vivências cotidianas e formas pelas quais os próprios sujeitos passam a olhar para si mesmos e seus modos de vida, dando sentido aos comportamentos e às relações tecidas uns com os outros no campo social (Werneck Vianna, 1999).

Já por psicologização destacamos a ênfase aos componentes afetivos, subjetivos e psicológicos nos discursos e práticas dos agentes de uma justiça tida como mais humanizada e sensível às questões emocionais dos conflitos familiares. Destarte, ao tecer uma leitura sobre as novas tecnologias de resolução dos conflitos familiares, percebemos uma série de produções discursivas e pedagogias moralizantes que embasam as práticas oficiais e se atrelam a um certo uso banalizado de ideias e técnicas da Psicologia, solidificando o que Schuch já identificava como uma tendência à "vulgarização dos saberes 'psi' como pedagogia do ser nos seus relacionamentos humanos e às vezes das próprias questões sociais" (Schuch, 2012:11). Ao empregar o termo "psicologização", buscamos então designar a incorporação de uma retórica e de um aparato técnico-discursivo associado à Psicologia que norteia os discursos e as práticas estatais, dando sentido às vivências dos sujeitos, descrevendo e produzindo realidades. 
Contudo, nossa abordagem não se limitou a analisar a família apenas como objeto de tais proposições, mas buscou ainda considerar a agência destes sujeitos que faz com que a judicialização e a psicologização se configurem como engrenagens operadas e alimentadas não só pelo Estado, mas também pelas próprias famílias que demandam a ação estatal para a resolução dos conflitos das mais diversas ordens que vivenciam. Nesse sentido, objetivamos explorar como os agentes, as políticas estatais e as próprias famílias operam com concepções, juízos de valor e referências que geram sentidos (por vezes, controversos) acerca das vivências familiares e das propostas oficiais de resolução de seus conflitos. Para tanto, colocamos em análise os sensos, os dissensos e as lógicas presentes na etnografia realizada junto às famílias - em geral, pais e mães - que passavam pelas Oficinas de Divórcio e Parentalidade no Cejusc.

Compondo parte da Política Judiciária Nacional proposta desde 2010 pelo Conselho Nacional de Justiça (CNJ), os Cejusc são descritos como as "células de funcionamento da Política Pública" de prevenção e resolução dos conflitos familiares no sistema de Justiça brasileiro, tendo como "peças-chave [...] os conciliadores, mediadores e demais facilitadores de solução de conflitos, bem como os servidores do Judiciário, aos quais cabe a triagem dos casos e a prestação de informação e orientação aos jurisdicionados para garantia do legítimo direito ao acesso à ordem jurídica justa" (CNJ, s/d.). Estando vinculado aos Núcleos Permanentes de Métodos Consensuais de Solução de Conflitos (Nupemec), o Cejusc tem relação direta com os tribunais de justiça de cada Estado, os quais seguem as diretrizes e normativas nacionais das práticas de conciliação e mediação de conflitos estipuladas pelo CNJ.

O Cejusc Polo Avançado - Manaus, onde essa pesquisa foi desenvolvida nos anos de 2018 e 2019, integra o Poder Judiciário do Estado do Amazonas e se caracteriza como um serviço de portas abertas à população, funcionando desde 2015 por meio de um Acordo de Cooperação Técnica com a UFAM, de modo a oferecer também atividades de cunho extensionista, de pesquisa e de formação para acadêmicos dos cursos de Direito, Psicologia e Serviço Social. Em linhas gerais, as demandas do local são relativas ao âmbito do Direito de Família, envolvendo questões referentes a divórcio, guarda de filhos, pensão alimentícia, reconhecimento de paternidade ou maternidade socioafetiva, partilha de bens, dentre outras. A proposta do Cejusc é de oferecer à população principalmente um serviço pré-processual e autocompositivo, isto é, caracterizado pela resolução do conflito por meio de um acordo produzido pelas próprias partes, sem a necessidade de um juiz, mas estimulado pela figura do mediador/conciliador. Ademais, com o intuito de diminuir as disputas judiciais, o Cejusc oferece ainda atividades tidas como preventivas, educativas e de auxílio às famílias, como as oficinas de parentalidade.

Considerada pelos interlocutores um carro-chefe do Cejusc, a Oficina de Divórcio e Parentalidade figura como uma das principais políticas conciliatórias do CNJ, inserindo-se no movimento de modernização e humanização da justiça por constituir uma "política pública na resolução e prevenção de conflitos familiares” (CNJ, 2014: s/p). A Oficina de Divórcio e Parentalidade vem sendo caracterizada como um "programa educacional, multidisciplinar e preventivo, sem fins lucrativos, com o intuito de harmonizar e de estabilizar as relações familiares, especialmente na fase de transição oriunda do rompimento da relação conjugal que gerou filhos" (CNJ, 2020:16). No Cejusc pesquisado, era denominada de Oficina de Pais, por se destinar especialmente aos pais e às mães (como outros familiares ou interessados) que passariam pela audiência de mediação/conciliação e que, conforme o CNJ 
(2020), estivessem "vivenciando conflitos surgidos em decorrência da mudança da estrutura familiar", necessitando, assim, "de auxílio para a reformulação de seus discursos e atitudes" (CNJ, 2020:16-17). O CNJ prevê, ainda, a Oficina de Filhos para as crianças e os adolescentes na faixa etária de 6 a 17 anos, porém a equipe local afirmava não ser possível realizar, devido ao número limitado de profissionais que possuíam na época.

No decorrer da pesquisa, acompanhamos mais de vinte oficinas e inúmeras famílias com seus conflitos, às vezes narrados, às vezes vivenciados no cotidiano das atividades do Cejusc. Em sua maioria, os sujeitos eram de camadas populares da cidade, muitos vindos do interior do estado do Amazonas em busca de melhores condições de trabalho, constituindo também relações afetivas e de parentesco que viriam a gerar vínculos de casamento e/ou coabitação. Nessa trajetória, a emergência de diferentes conflitos (brigas, traições, agressões, ciúmes, dentre outros) levavam ao desenlace afetivo e faziam com que as famílias buscassem o sistema de Justiça. No Cejusc Polo, as principais demandas identificadas ao longo da pesquisa diziam respeito às dificuldades de comunicação entre o ex-casal, às suspeitas dos homens em relação à paternidade biológica, às queixas das mulheres em relação à ausência dos pais e ao pagamento de pensão, dentre outros pontos em geral circunscritos à dificuldade de manutenção do vínculo parental após a ruptura conjugal.

A procura pelo Cejusc Polo se dava de forma voluntária, geralmente por meio da indicação de algum conhecido que passou pelo serviço e que resolveu seu problema, ou por meio de encaminhamentos oficiais, como das varas de família, visando resolver a questão de forma pré-processual. Boa parte das solicitações iniciais partiam das mulheres que se queixavam da ausência de apoio financeiro dos homens, havendo alguns casos pontuais de pais que procuravam o serviço para buscar maior convivência com seus filhos que residiam com a mãe. Configurando-se a demanda como conflito familiar, os sujeitos envolvidos (chamados de "partes") eram convidados a participar da chamada Oficina de Pais, uma das primeiras intervenções no fluxo de atendimentos da instituição, realizada sobretudo antes das audiências de mediação/conciliação.

As oficinas eram conduzidas por profissionais e estagiários dos cursos de Psicologia, Serviço Social e Direito, seguindo as diretrizes e materiais didáticos produzidos pelo CNJ, apresentando desde dados estatísticos sobre o divórcio, artigos de leis, orientações jurídicas, até conteúdos sobre sentimentos, listas de comportamentos tidos como prejudiciais, vídeos sobre comunicação não violenta, dentre outros. Estes encontros aconteciam em grupos que variavam de duas a 30 pessoas, com o objetivo de contribuir para atenuar o conflito familiar e preparar as partes para a audiência de conciliação.

Ao longo da pesquisa, percebemos que a abertura para fala dos participantes era por vezes considerada um problema, já que geralmente remetia aos seus conteúdos e histórias mais íntimas, mesmo com os recorrentes avisos dos expositores de que ali não seria o espaço adequado para conteúdos pessoais. Dessa forma, o incentivo à participação das famílias se limitava a alguns momentos específicos, como quando eram propostas dinâmicas, em caso de dúvidas sobre os trâmites judiciais ou na avaliação final da oficina.

Todavia, dado o cunho educativo dos encontros, havia momentos de diálogos entre as famílias e os agentes que nos permitiram rastrear as recorrentes chaves explicativas, sentidos e modelos trazi- 
dos pelos próprios sujeitos para se referirem às suas vivências, como também fornecidos pelos agentes da justiça humanizada na busca da harmonização daquelas relações. Apresentamos, a seguir, algumas cenas presenciadas nas oficinas que se configuraram como categorias emergentes no campo, as quais não decorrem somente de temas abordados pelos expositores que construíam discursos permeados por valores morais culturalmente localizados, mas abarcam também as experiências, os sentidos (nem sempre partilhados) e as regularidades que foram apreendidas a partir do diálogo com as famílias. Homens e mulheres envolvidos em conflitos não resolvidos e levados ao Cejusc para serem mediados e que recorriam mais a uma espécie de justiça vingativa, apresentando suas versões lógicas para terem razão no embate e vencerem o processo. Assim, discorreremos acerca de quatro principais (dis)sensos trazidos pelos interlocutores e selecionados para a discussão neste artigo, a saber:

1. O divórcio destrói a família;

2. A mulher-mãe sempre fica com os filhos;

3. O homem-pai deve pagar pensão;

4. O homem-pai tem a obrigação de dar afeto aos filhos.

Geralmente, tais pontos se configuravam como queixas recorrentes nas oficinas e nas audiências de mediação e giravam em torno de um embate entre homens-pais $\mathrm{x}$ mulheres-mães que trouxe à tona as construções discursivas e lógicas locais em torno dos papéis parentais e das posições ocupadas por homens e mulheres nos modos de funcionar das famílias.

\section{O divórcio destrói a família}

A Oficina de Pais costumava enfatizar o tema dos conflitos oriundos da separação conjugal e de como isso seria prejudicial aos filhos. Aparentemente, soaria óbvio falar de divórcio no contexto de um centro judiciário voltado para resolução de conflitos familiares. Contudo, aos poucos, começamos a perceber os diferentes sentidos, perspectivas e (in)compreensões, nem sempre partilhados entre os interlocutores, acerca de duas "unidades mínimas ideológicas" que, tal como Velho (2010) indica, emergiram no campo sem que possuíssem um significado previamente dado, mas que eram frequentemente colocadas em oposição: o divórcio e a família. Assim, apesar das importantes problematizações presentes na literatura antropológica acerca das modificações e tensões que envolvem as relações familiares atualmente, abordaremos aqui as lógicas dos sujeitos que apareceram no universo pesquisado e que sinalizaram a necessidade de retornarmos a alguns questionamentos basilares: o que os sujeitos têm entendido por divórcio? A partir de quais referentes e pontos de vista dão sentido ao que chamamos de família? De que modo percebem as correlações entre essas duas categorias? Tais questões emergiram na relação com os interlocutores e com o campo de pesquisa, após experienciar com certa regularidade falas e discursos similares a este que trazemos a seguir, vivenciado em uma das oficinas. 
“Na opinião de vocês, o divórcio acaba com a família?” - questionou a expositora da Oficina² em mais um encontro com os pais, logo depois de exibir um vídeo que ilustrava por meio de imagens e histórias os diferentes tipos de família reconhecidos atualmente (nuclear, monoparental, ampliada, homoafetiva, recasada, dentre outras). Depois de um certo silêncio e troca de olhares dos participantes, João Valério ${ }^{3}$, um homem de 53 anos de idade recém-separado e participante da Oficina, se arriscou:

Com certeza, minha filha! O que Deus uniu o homem não separa... Eu fico até meio envergonhado de estar aqui nessa situação, sabe... Mas a vida tem dessas coisas né? Nunca imaginei que passaria por isso, mas sei que tenho minha culpa, deveria ter tentado mais... o problema é que a gente é falho né? Perde a paciência um dia, se mete onde não deveria... vou carregar esse arrependimento para o resto da vida.... Uma coisa eu sei, a gente não está aqui nessa manhã por acaso! Eu sei que eu estou todo errado, mas quero deixar uma palavra para vocês que Deus colocou no meu coração nesta manhã: continuem acreditando na família! Deus não fez o homem para viver só! Eu falo por experiência própria: o divórcio destrói a família! Não deixem isso acontecer, façam de tudo para perdoar e manter o lar de vocês, nem que seja pelo bem das crianças...

Lembramos, com o auxílio do diário de campo, que não era a primeira vez que ouvíamos essa modalidade de discurso na oficina, e nem mesmo no contexto jurídico. Entre os agentes estatais, ele se (con)fundia à máxima do que se dizia ser o "direito dos filhos à convivência familiar" que, com o divórcio, despertava ainda mais a atenção e a intervenção da justiça humanizada e do movimento de consensualização dos conflitos familiares. Na maior parte das vezes, o principal argumento evocado era de que o divórcio não era um problema em si, mas sim a forma conflituosa como os pais e parentes lidavam com ele, sobretudo quando envolvem os filhos e negligenciam os supostos e temerosos efeitos adversos decorrentes dos conflitos para as crianças. Tal ideia geralmente se ancorava em uma linguagem psicologizante centrada no fator trauma, o qual permanecia como sombra e ameaça para as famílias que passavam pelas oficinas e ouviam falar dos inúmeros danos nefastos supostamente ocasionados aos filhos por seus próprios pais. Por vezes, o discurso oficial se aproximava bastante da fala de João Valério, como vemos na apresentação da chamada Cartilha da família - não à alienação parental (Tribunal de Justiça da Bahia, 2013), a qual compõe um conjunto de artefatos produzidos e empregados no contexto dos Cejusc e tribunais de justiça do país:

O homem se unirá à mulher e os dois serão uma só carne". Assim, "O que Deus uniu, pela concepção ou pela adoção, o homem não pode separar”; ou seja: os responsáveis pelas crianças e adolescentes não podem ferir ou cercear direito fundamental delas; ao contrário, devem transformar toda e repudiada forma de alienação parental em tempo de esperança e em lugar de harmonia e paz entre Pais, Filhos e Familiares da presente e futuras gerações. (Tribunal de Justiça da Bahia, 2013:s/p).

2 No campo etnografado, os expositores eram geralmente profissionais e estudantes dos cursos de Psicologia, Serviço Social e Direito que atuavam como estagiários no Cejusc, predominando no local a presença de mulheres nas três áreas.

3 A fim preservar a identidade dos interlocutores de pesquisa, optamos por adotar nomes fictícios. 
Destarte, tanto nos discursos oficiais quanto nas falas dos participantes da Oficina de Pais, tal retórica se tornou muito recorrente e sinalizava as proximidades e os tensionamentos existentes entre dois referentes culturais balizadores das relações sociais e das subjetividades: a família e a religiosidade ${ }^{4}$. João Valério e muitos outros interlocutores aproveitavam então aquele espaço para esboçar uma espécie de "sermão" sobre a preservação da família nuclear como uma resposta ao usual questionamento feito pelos expositores da oficina acerca do caráter supostamente destrutivo do divórcio.

Um senso comum trazido tanto por homens quanto por mulheres durante a oficina, quer fossem casados no papel ou não, era de que a família tal como concebida no imaginário social acabou, foi destruída com o divórcio. Muitos se queixam das falhas do outro como esposas ou maridos, enquanto alguns chegam até mesmo a afirmar que, apesar de estarem vivenciando a separação, não concordavam com o divórcio, como no caso do seu João Valério. Nesse sentido, não foram raras essas compreensões trazidas pelos sujeitos de que o divórcio significou abalo ou destruição da família. Assim, pudemos compreender os impactos gerados pela dissolução do casamento nas formas de se pensar e conceber a família. De modo geral, notamos que o fim da relação conjugal, mais do que uma vivência frustrante, simbolizava um certo fracasso no ideal do "viveram felizes para sempre", além de estar atrelado aos valores religiosos presentes em nossa cultura, partilhados também pelos agentes da justiça humanizada. Por vezes, esse assunto surgia nas conversas informais dos estagiários e profissionais do Polo, os quais diziam quase em tom de confissão que ainda tinham esperanças de ter um casamento feliz e que lamentavam quando acompanhavam alguma família que estava experienciando o divórcio.

Contudo, vale ponderar que tal perspectiva, apesar de se configurar com certa recorrência, não era unânime nem entre os agentes nem entre os participantes das oficinas. Ao compartilhar suas experiências e opiniões sobre o divórcio, muitos homens e mulheres se referiram a sensações distintas com o término do relacionamento afetivo, como medo, frustração, indiferença, paz, liberdade, realização, alívio, felicidade, etc., o que denota a multiplicidade de expressões e a variabilidade de significados construídos por eles para se referirem a essa vivência, sem necessariamente pender para um viés negativo. Foi como se expressou Miranda Leitão naquele mesmo dia de oficina, logo após ouvir a opinião de João Valério:

Seu João Valério, bom dia. Meu nome é Miranda Leitão. Obrigada por compartilhar sua opinião hoje aqui, mas eu queria te fazer uma pergunta: o senhor falou antes que tem um filho né? E depois do divórcio, seu filho continua sendo parte da sua família, certo?

Então, seu João, com todo respeito, sua família não acabou! Eu compreendo seu ponto de vista, mas posso falar também da minha experiência: foi uma leseira casar só porque eu era adolescente e me vi grávida, com toda aquela pressão da família... ele era muito ciumento e eu achava que era normal né... mas depois que a bebê nasceu, eu não aguentei um mês e voltei para a casa da minha

\footnotetext{
4 Apesar de não compor parte do escopo da pesquisa, percebemos entre os sujeitos que procuravam o Cejusc o predomínio de narrativas que expressam valores e concepções da tradição católica sobre a família nuclear, ao mesmo tempo em que incorporam os elementos de um discurso pentecostal condenatório de algumas práticas que a destruiriam, em especial, o divórcio. Tais discursos foram recorrentes em boa parte das oficinas etnografadas, bem como em outros momentos de diálogo com as famílias, as quais sustentavam a ideia de que a família deveria permanecer unida, de que o divórcio não deveria ter acontecido e de que a separação seria um erro.
} 
mãe... vai fazer quatro anos que eu me separei do pai da minha filha: a melhor coisa que aconteceu na minha vida! - ela conclui.

A fala de Miranda Leitão se tornou representativa de outros participantes que afirmavam os desdobramentos positivos do divórcio em suas vidas. Especialmente quando a relação com o/a ex-cônjuge era conflituosa ou mesmo marcada por violências, os relatos salientaram ainda mais a experiência de liberdade e felicidade trazida pela separação. Nesse ponto, foi interessante notar as diferenças das narrativas e o quanto elas evidenciaram a importância dos marcadores de gênero na construção de sentidos acerca das relações e conflitos familiares. Assim, a ideia de que o divórcio destruiria a família possuía forte apelo moral, tendo como corolário um certo (contra)senso: por vezes, aquele/a que se intitulava como "defensor/a da família" (leia-se: a família nuclear, capaz de superar conflito e permanecer casada), era o/a mesmo/a que se ausentava de suas responsabilidades parentais (o que, no caso dos homens, era mais recorrente pelo fato de não residirem mais com os filhos), especialmente quando estabeleciam novos casamentos e filiações. Tal perspectiva não anulava a ideia de que o divórcio pode ser também uma experiência positiva, pois possibilita novos relacionamentos, configurações de família, além de, no caso especialmente das mulheres, fortalecer os sentidos e o reconhecimento social de suas posições de mães. Ademais, havia na cena jurídica alguns modos predominantes de agenciamento desses sujeitos especialmente em relação à lógica da vitimização e da punição dos comportamentos alheios, acionada pelas mulheres quando se viam sem apoio - sobretudo financeiro - e pelos homens quando tinham dificuldades de permanecer em contato com os filhos por conta dos conflitos com a ex-mulher.

Ao conhecer a história de vida daquelas famílias, foi curioso perceber também que a grande maioria não tinha sequer estabelecido o contrato formal ou a aliança religiosa do casamento, havendo uma certa regularidade com que expressam modos locais de ser e constituir família no Amazonas. De modo similar aos registros decorrentes da etnografia realizada por Lima (2018), muitos dos interlocutores relataram que a composição de um novo núcleo familiar decorreu de uma gravidez inesperada, por vezes na adolescência, que motivava a saída da mulher da casa dos parentes para compor um lar com o genitor de seu filho/a. Assim, o fato de experienciarem a coabitação era o suficiente para se reconhecerem enquanto "casados" e experimentarem uma espécie de "culpa" - e/ou culparem o outro - por não terem sido capazes de assim permanecer quando vivenciavam a separação.

Por outro lado, identificamos também casos em que não fazia sentido para os participantes estar na oficina, falar em divórcio e nem mesmo em família, haja vista que suas experiências sexuais não geraram quaisquer vínculos ou vivência de casamento com o(a) parceiro(a). Para estes sujeitos, geralmente homens, a filiação biológica não constituía em si um elemento fundador da família e da parentalidade, caso não tivesse como desdobramento o casamento ou a coabitação. Assim, a relação consanguínea decorrente de uma dita gravidez inesperada não era um elemento suficiente para que se reconhecessem como família, de modo que eles se referiam a estas experiências sexuais como uma "aventura”, um "caso" ou mesmo "nada".

Nestas situações, em especial, as mulheres costumavam encontrar certas saídas comuns. Algumas assumiam o papel de "mãe solteira", permanecendo na casa de seus parentes que as auxiliavam no 
cuidado com os filhos - papel geralmente assumido pelas avós - enquanto trabalhavam e desenvolviam suas atividades no espaço público. Especialmente nessas configurações, a maioria dessas mães buscava na justiça a solução para o problema da pensão: afinal, "não fizemos filhos sozinhas", elas ironizavam. Mas havia também aquelas mulheres, como Jacira Reis, que diziam ter decidido "tocar suas vidas" no sentido de estabelecer uma nova família com outro parceiro, o qual era tido como "marido de referência”, ou seja, aquele que se tornava "o pai de todos os seus filhos" (Lima, 2018:108):

É como eu digo, pai não é aquele que faz não, fazer é mole... pai é quem cria, quem dá as caras ali no dia a dia... No meu caso, o pai mesmo nunca quis nem saber do menino, ainda mais depois que foi lá para as bandas do interior... agora precisa ver o meu esposo: um grude só. Como eu passo o dia na casa da minha patroa e ele tem uma oficina nos fundos da casa, é ele que cuida, dá comida, leva pra escola, vai no hospital, ajuda com as lições... Quando a gente se juntou, eu já tinha o mais velho, que não tinha nem um aninho ainda... depois veio mais três, mas lá em casa não tem diferença de um filho pro outro não... Tanto que o mais velho nunca veio com essa história de querer morar com o pai... Pra você ver, doutora, eu nunca ensinei, mas ele mesmo chama o meu esposo de pai... Não tem jeito, depois de anos morando juntos e crescendo com ele, não tinha como não ser assim...

A perspectiva de Jacira Reis era comum também entre muitas interlocutoras cujos companheiros assumiram o papel e o status de pai dos filhos oriundos de seus relacionamentos anteriores. Era o que os expositores da oficina chamavam de famílias recasadas, mas que, na lógica dos sujeitos, não fazia sentido chamá-las assim, já que se reconheciam como uma família nuclear, noção que se atualiza nas vivências cotidianas, passando a abarcar "várias normalidades possíveis entre as práticas familiares", como nos lembra Fonseca (2002:55). Tais casos costumavam chegar ao Polo por meio das demandas de reconhecimento de paternidade/maternidade socioafetiva, aquela cuja filiação não tem origem biológica ou adotiva, mas deriva da construção de um vínculo afetivo e parental gerado pela convivência - o que as famílias chamavam de "pais de criação". Essas dinâmicas e configurações familiares eram bem-vistas e aceitas, o que nos faz concordar com Fonseca (2002:51), que afirma que "a compreensão da vida familiar no Brasil contemporâneo exigiria do observador um esforço para considerar, além da norma hegemônica, essas dinâmicas alternativas".

Apesar do discurso oficial argumentar que esse não era um modelo substitutivo, ou seja, que o pai socioafetivo não excluiria o outro pai (biológico), as vivências dos sujeitos apontavam o contrário, como explica o marido de Jacira:

Lá em casa sou eu, a Jacira e mais quatro bocas para alimentar, doutora... Fácil não é não, a gente trabalha duro todo dia, se sacrifica pela família... Claro que eu não quis substituir o pai dele, mas eu tava até falando disso ontem para o juiz: na prática foi o que aconteceu... Olha doutora, para mim filho é muito mais que um nome no papel, entende? Isso qualquer um faz! Não foi ele [o pai biológico] que decidiu curtir a vida no interior e deixou o menino aqui desamparado com a mãe? Pronto! Para mim isso não é homem não, doutora... Quando eu conheci a Jacira, prometi para ela que ia cuidar dele como meu e que ia levar eles para minha casa... por isso hoje a gente tá aqui... 
Vemos assim que, mesmo com as intervenções dos expositores da oficina buscando ampliar os sentidos do que é ser família, predominava nas falas dos sujeitos à referência de um modelo nuclear, ficando evidente o quanto culturalmente a ideia de família e a parentalidade ainda se vincula ao casamento - opinião defendida por João Valério - e à coabitação - perspectiva sustentada na história de Jacira Reis. Destarte, o sentido de que "o divórcio destrói a família" expressava os impactos nos papéis parentais, as mudanças na família e as dificuldades dos mais diversos tipos que emergiam nas relações entre os homens e as mulheres.

\section{A mulher-mãe sempre fica com os filhos}

Desde o início dos anos 2000, a questão da divisão de responsabilidades e da igualdade de convivência com os filhos após a separação conjugal tem estado presente nos discursos acadêmicos, estatais e até mesmo em movimentos de homens-pais separados, tornando-se figurativa no contexto jurídico a chamada guarda compartilhada. Apesar de ter sido convencionada como regra e pressupor a construção de uma nova lógica em que ambos os genitores são mantidos como responsáveis e guardião dos filhos, pudemos perceber um movimento recorrente nas formas das famílias se organizarem e do próprio Judiciário intervir no Amazonas, o qual refletia um senso comum de que os filhos ficam sempre com a "mulher-mãe".

Tomamos emprestada aqui a categoria utilizada na etnografia feminista sobre maternidade desenvolvida por Salazar (2020), na medida em que esta sinaliza uma colagem culturalmente estabelecida e naturalizada entre a experiência da maternidade e a subjetividade feminina, como se "ser mulher" implicasse, inevitavelmente, em ser/torna-se uma “boa mãe". Conforme sinalizado em seu estudo, é preciso considerar as variantes do contexto contemporâneo que possibilitam experiências distintas de maternidade e que forjam - ao menos no imaginário social - mulheres-mães informadas, psicologizadas, conscientes, portadoras de direitos e reivindicantes de condições igualitárias em relação aos homens. Contudo, é necessário salientar os conflitos entre essas novas experiências e as diferentes realidades vivenciadas por tais mulheres-mães, como pudemos perceber no nosso contexto de pesquisa.

Foi com certa surpresa que ouvimos das mães, dos pais e mesmo dos agentes falas que centralizavam nas mulheres a função do cuidado, da responsabilidade e da dedicação em relação aos filhos. Apesar de as mulheres se queixarem o quanto tais atribuições se acentuavam com o divórcio e/ou a ausência paterna, elas também sustentavam a condição sacralizada da mulher-mãe em detrimento da presença e participação ativa dos pais no cotidiano dos filhos, cuja perda era tida como um ônus do conflito familiar, tal como vemos no relato de Jacira Reis:

Meus filhos são tudo para mim, doutora. Olha, eu acho que se ele (o pai biológico) ou algum juiz se atrever a tentar tirar o menino de mim... nem sei, eu perco a cabeça... Quem é mãe sabe do que eu tô falando! Hoje em dia eu acho até bom que ele tenha ido embora fazer a vida dele, se arranjado com outra mulher por lá... Quando a gente tava junto, toda semana tinha briga por conta das saideiras dele, da bebida, mas eu era boba, menina, cega de amor. Até que eu engravidei e achei que um filho ia mudar... Como a gente tava ainda construindo nossa casa e eu era muito novinha, 
doutora, decidi ficar na casa da minha mãe quando o menino nasceu... só que era assim, a casa da minha mãe aqui e a nossa mais pro final do beco, tudo muito perto. E sabe o que ele me aprontou, doutora? Arrumou de levar uma piriguete pra lá e não tinha nem um mês que eu tinha parido o filho dele... Ah, mas eu não deixei barato não, fui lá e dei uns bons tabefes nos dois... Ali eu decidi que não dava mais, peguei todas as minhas coisas, fui pra casa da minha mãe e disse que não era para ele dar as caras por lá... Fácil não foi, doutora, mas eu precisava ser forte e pensava que não era esse o tipo de homem que eu queria que meu filho se tornasse... Lembrei que cresci vendo minha mãe apanhar do meu pai toda vez que ele chegava das bebedeiras dele, e decidi que não seria assim comigo não... Preferia um filho sem pai! Agora tu achas que ele fez questão? Nunca me ligou e fiquei sabendo que ele só chegou a tentar ver o menino umas 2 vezes... depois logo mudou para o interior quando perdeu o emprego aqui dele no Distrito e só agora que eu tive notícias...

A narrativa de Jacira coincidia com a de muitas mulheres-mães que compartilhavam a experiência de ausência dos pais de seus filhos. Havia um senso partilhado entre elas de que a separação enquanto uma forma de resolver o conflito daquela relação com o ex-parceiro implicava inevitavelmente no distanciamento não só do marido, mas também do pai. Apesar dos discursos oficiais sobre a guarda compartilhada e a própria proposta da oficina sustentar uma lógica distinta - de valorização da convivência com ambos os pais enquanto um direito dos filhos e da importância de os adultos serem capazes de separar a relação conjugal conflituosa da relação parental -, percebemos que os agentes também reproduziam os referentes de gênero presentes nas construções sociais acerca dos papéis parentais de homens e mulheres na família.

Tal ideia implicava em uma dada leitura oficial sobre a forma da família funcionar e um dado modo de resolver os conflitos no Cejusc: mais do que chegarem ao "acordo" da guarda compartilhada, cujas vantagens eram fortemente salientadas pela equipe, havia um entendimento comum de que a residência da criança seria naturalmente a da mulher, "afinal, qual o juiz que vai tirar um filho de uma mãe?", concluiu uma das expositoras ao abordar o assunto para os participantes da oficina. As justificativas remetiam desde a um fundamento da natureza, como de que "mãe é mãe", como também a um discurso psicologizante que salientava a maior vinculação emocional da criança com a figura materna, sobretudo durante os primeiros anos de vida.

Destarte, nos acordos de guarda compartilhada feitos no Cejusc, costumava-se estabelecer o que era chamado de residência sede da criança, ou seja, a casa que ela teria como referência de sua moradia, que geralmente era a da mãe. Em paralelo, estabelecia-se também o que os mediadores chamavam de "direito de visita" (ou de convivência, como a lei denomina) do pai ou genitor com o qual a criança não residiria, que em geral ficava circunscrito a um ou dois dias na semana (para não atrapalhar a rotina da criança, como argumentavam) e a fins de semana alternados. Com efeito, as responsabilidades cotidianas (como levar para a escola, cuidar, ir ao médico, etc.) acabavam se acumulando sobre as mães e o núcleo familiar onde a criança tinha sua moradia estabelecida, não ocorrendo na realidade aquilo que a legislação prevê como um compartilhamento de responsabilidades entre ambos os genitores.

As exceções à regra da criança residir com a mãe só se aplicavam em duas ocasiões: caso a mulher não se enquadrasse na figura de "boa-mãe" ou por situações de morte. Nestas condições, assumiria 
então o pai a posição de guardião? Na maioria das vezes, não. Era comum entrar em cena as figuras femininas da família, como as avós ou as tias. Quando o pai de fato conseguia e queria figurar como responsável principal, geralmente era com o respaldo da presença de uma mulher, por exemplo, sua esposa atual ou sua mãe, como se sozinho ele não fosse capaz de exercer plenamente os cuidados de uma criança.

Por último, uma particularidade que identificamos no universo pesquisado dizia respeito às trajetórias migratórias e à ampla mobilidade espacial dos sujeitos que, após desfazerem um núcleo familiar, se viam com a necessidade de reorganizar suas vidas. Assim, eram comuns casos como o de Jacira, em que o pai ou a mãe retornaram para o interior do estado pelas dificuldades de se manterem na capital ou por poderem contar com o auxílio dos parentes que haviam deixado lá; bem como, ao contrário, irem para a capital, onde poderiam oportunizar melhores condições de vida aos filhos; além de estabelecerem um novo casamento e mudarem até mesmo para outro estado e região do país acompanhando a nova família. Disso derivava a necessidade de os pais entrarem em acordo e regularizar a questão da guarda e da pensão dos filhos, motivo que os levava ao Cejusc e que figurava nas audiências como o principal conflito. Percebemos também que esse se tornava um impasse até mesmo para os profissionais, que não tinham como assegurar a ampla convivência da criança com ambos os genitores, já que, na maior parte das vezes, as famílias não tinham condições financeiras de arcar com viagens regulares entre cidades ou estados distintos garantindo a circulação dos filhos. Nestes casos, além da permanência do fundamento de que "a mulher mãe sempre fica com os filhos", se tornava notório o corolário de que o pai teria como obrigação o pagamento da pensão, conforme desenvolveremos a seguir.

\section{O homem-pai deve pagar pensão}

Em mais um dia de oficina, novamente registramos algo que despertava bastante a atenção: apesar de nunca terem se visto antes, os participantes já começavam a apresentar uns com os outros uma postura adversarial e provocativa, a partir de suas posições de homens-pais e mulheres-mães.

Estávamos em um dos momentos em que a expositora, uma estudante de psicologia, se propunha a falar sobre os sentimentos dos filhos em relação ao divórcio dos pais. Para tanto, ela apresentava um desenho feito por uma criança, uma figura humana com um balão de fala com caveira, exclamação, hashtag e outros símbolos geralmente usados nas histórias em quadrinhos para suprimir xingamentos e outras expressões de raiva:

"Este é mais um desenho que foi feito por uma criança que vivencia o divórcio dos pais. O que podemos observar aqui?" - a expositora questiona os participantes.

“O pai tá enraivado!" - diz de forma enfática um homem que assistia à oficina, provocando algumas risadas.

"Aconteceu alguma coisa..." - ele complementa em tom irônico.

“Ele não quer pagar a pensão!” - rebate uma das mulheres participantes, enquanto os demais riem novamente. 
“É, mas não tem que falar com o curumim! Tem que falar com a mãe!” - diz o homem em resposta ao seu comentário.

Tomaremos a questão do pagamento da pensão enquanto um símbolo de um embate entre homens/pais e mulheres/mães que reflete as relações entre a Justiça e as famílias. Se à mulher caberia ainda o papel fundamental, natural e inquestionável de cuidado dos filhos (como mãe-guardiã), do homem era esperado minimamente o pagamento da pensão (enquanto pai-provedor). Tal lógica era muito comum nas oficinas, ao mesmo tempo em que costumava ser um ponto polêmico entre os participantes, que expunham suas histórias de vida em busca de orientação. Por sua vez, esse era um tópico trazido pelos expositores - especificamente, os estudantes de Direito - que ficavam encarregados de abordar os aspectos legais e jurídicos relacionados ao pagamento da pensão, na medida em que era um dos quesitos que mais geravam conflitos nas audiências.

A maior parte dos homens-pais se queixava do valor que as mulheres reivindicavam nos casos que envolviam a definição da pensão, colocando sob suspeita o uso que as mães poderiam fazer do dinheiro, como expressou um dos participantes:

Eu queria saber se ela pode exigir tudo isso de mim, porque agora ela inventou que quer praticamente metade do que eu ganho. Hoje eu dou um dinheirinho por mês mais o rancho deixei de lado meu compromisso não, tenho tudo aqui para provar pro juiz: meu contracheque, as contas do mercado que eu mesmo passei a fazer... mas não sei com que ela tanto gasta que chega na metade do mês o dinheiro evapora... e agora tem essa de querer me processar... será se ela pode mesmo? Disseram que era melhor eu ir na Defensoria antes da audiência, mas só consegui vaga para mês que vem... se vocês puderem me ajudar nisso...

Diante de falas como essa, as mães costumavam reagir apontando as necessidades dos filhos e acusando os homens de não assumirem a responsabilidade de sustentá-los financeiramente:

"Engraçado que na hora de fazer ninguém reclama! Aí depois que coloca a criança no mundo, tudo muda... nós mulheres temos que se virar para dar conta de cuidar de tudo sozinha! No meu caso, o pai acha que 200 reais por mês resolve e não dá nem para comprar comida direito... Eu ainda tive que ouvir a desculpinha de que ele nem sabia se podia ter filhos... disse para ele que pagasse um DNA, mas passando necessidade com criança pequena eu não vou ficar... Por isso eu vim aqui atrás dos meus direitos, porque meu filho não é filho de boto não...", compartilhou uma das mães em tom de indignação.

"Comigo é a mesma coisa, o pai acha que criança não gasta com roupa, remédio, comida... semana passada mesmo a Juci [filha] pegou uma virose dessas e eu não consegui a medicação no posto... Eu faço unha em casa, não sobra dinheiro não doutora, então tive que arrumar emprestado com a pastora porque ele não me atendia e a menina ardia em febre... Sabe o que eu fiz? Só tirei foto da nota e mandei no WhatsApp, não deu cinco minutos e ele me ligou todo afobado, cheio de grosseria comigo, falando que eu tinha torrado o dinheiro, que ele não tinha como me dar nada agora,

5 Expressão local para se referir à cesta básica. 
que ia descontar do mês que vem... quando eu falei que tinha pegado emprestado com a pastora, ele chamou um palavrão e bateu o telefone na minha cara... Mas no dia seguinte foi lá deixar o dinheiro para ela, já comigo é sempre uma dificuldade!", compartilhou outra mãe sua história em identificação com a primeira.

Tais perspectivas costumavam ser conflitantes entre si por girar em torno da ideia de que somente o homem paga pensão para a mulher, segundo o modelo do pai provedor e da mãe guardiã/ cuidadora. Ademais, esse ponto costumava acirrar uma lógica binarista e adversarial que circunscrevia os conflitos familiares a uma espécie de "guerra dos sexos", de modo que os pais e mães participantes da oficina faziam acusações mútuas. Mesmo não possuindo relações entre si, eles falavam de suas posições de homens, mulheres, pais e mães. Assim, surgiam preconcepções como de que a mulher "quer se aproveitar", "gasta o dinheiro com roupa, unha e salão", "está tentando se vingar", "inventou de querer dinheiro por ciúmes", dentre outras falas que os homens traziam. Por sua vez, as mães contra-argumentavam fazendo menção ao "seu direito" de receber a pensão, bem como às ideias de que o homem "tem que servir pelo menos para isso", "só quer saber de farrear e bancar as namoradinhas", "fica mendigando com o próprio filho(a)", "abandonou os filhos", "precisa ser obrigado a ajudar financeiramente”.

Como boa parte das famílias que acessavam o Cejusc eram de camadas populares, pudemos observar que nem todas as mães se faziam valer do judiciário para regularizar a questão da pensão em um primeiro momento. Havia um intervalo de tempo entre a dissolução da relação e/ou coabitação e a demanda judicial, no qual as combinações e os arranjos eram feitos entre os próprios sujeitos: em geral, os homens ajudavam com o rancho e/ou uma quantia financeira, apesar de também não ser incomum eles não oferecerem nenhum tipo de auxílio às mães. Mas esse não era o principal motivador que as fazia buscar a justiça: além de obter o direito à pensão, elas esperavam penalizar o comportamento de seus ex-parceiros que se afastaram dos filhos. Assim, o argumento da prisão se fazia presente como um recurso acusatório para as mães e como elemento de coerção para os pais, sendo que ambas as lógicas eram reiteradas pelos expositores das oficinas, a maioria dos quais, vale lembrar, também eram mulheres.

Em um dos encontros, uma participante colocou em xeque a credibilidade do acordo, afirmando que possivelmente seu ex-companheiro não cumpriria o pagamento do valor estipulado, fazendo somente "cena na frente do juiz". De imediato, a expositora reagiu em tom indignado: "Mas tem que cumprir sim! É obrigação do pai pagar! E se ele não pagar? Aí vai preso, simples assim!”. Tal retórica, que evidencia bem o teor punitivo e judicializante dado às problemáticas sociais, nos remeteu aos discursos oficiais presentes em imagens que são divulgadas no Facebook do CNJ, no intuito de popularizar questões jurídicas, tal como as que vemos a seguir: 
Figura 1: Postagem do CNJ sobre Pensão Alimentícia

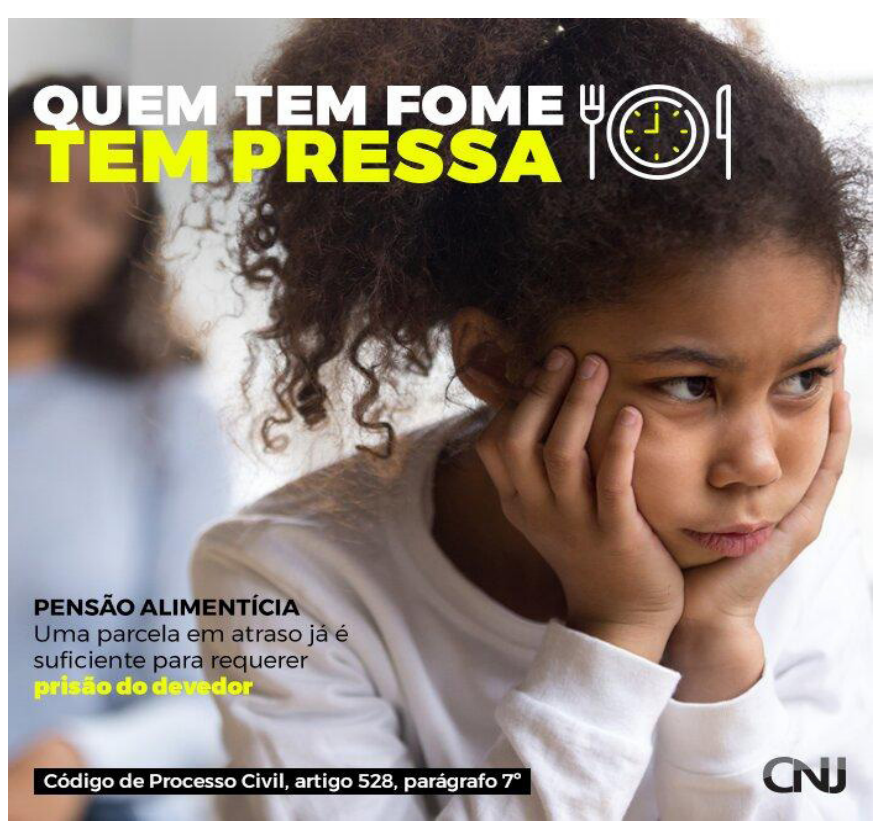

Fonte: CNJ, 2019.

Figura 2: Postagem do CNJ sobre Pensão Alimentícia

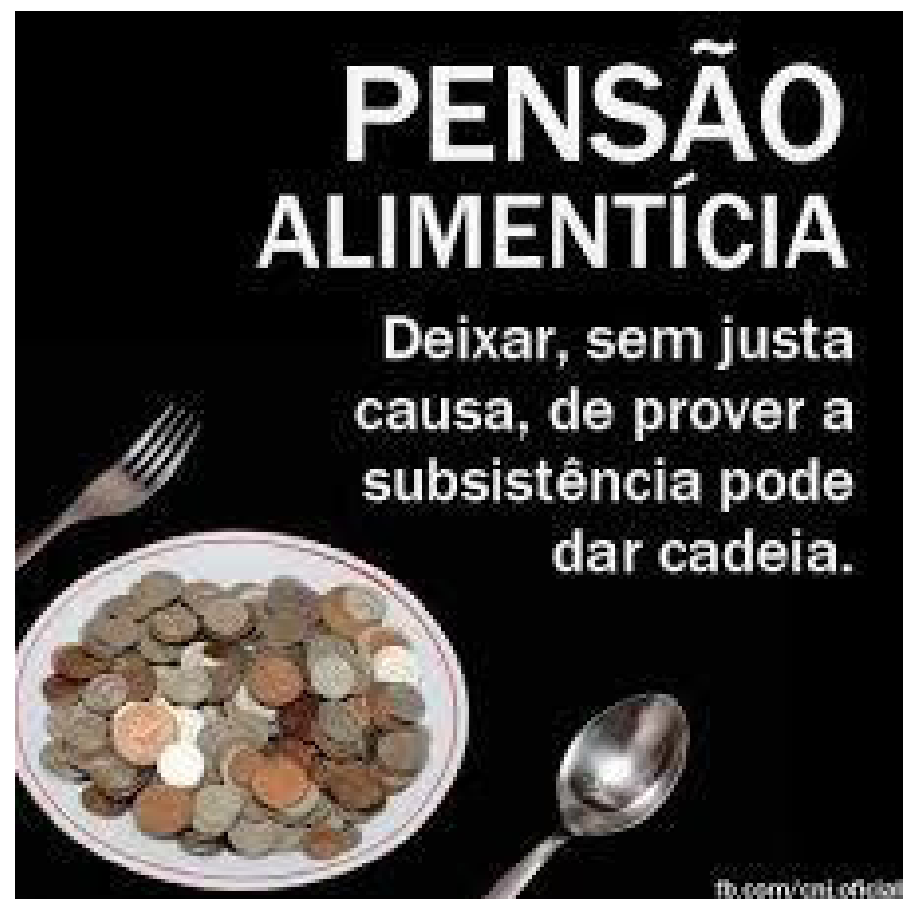

Fonte: CNJ, 2015b.

Quando o debate se intensificava nesse quesito, os expositores costumavam mediar as falas trazendo o enfoque para os filhos e buscando desmistificar a ideia de que o dinheiro é para a mãe. Contudo, era comum eles estabelecerem em seus discursos as associações "pai + pensão" e "mãe + guarda", reforçando as construções de gênero em torno dos papéis do homem e da mulher na família. Em uma dessas ocasiões, Max Teixeira, um pai cuja vivência era bem distinta da maioria dos casos, questionou quando um dos expositores da oficina falava dessa "obrigação do pai de pagar pensão à mãe": 
“Quer dizer então que só a mulher tem direito de receber pensão?” - retrucou Max Teixeira.

“Ótima questão, senhoras e senhores! Na verdade, não, pois a pensão é para os filhos! Aqui no Polo funciona assim: na audiência, quando a gente define quem fica com a residência sede, já tratamos da questão dos alimentos... Como na maioria das vezes o filho fica na casa da mãe, o pai paga a pensão... Mas nada impede que seja o inverso também!" - esclareceu o expositor daquele dia. "Engraçado, porque nunca ouvi falar de nenhum homem pedindo pensão da mulher. Porque o que aconteceu comigo foi diferente, a mãe largou as meninas comigo e sumiu por sete anos. No começo eu contei muito com a ajuda da minha mãe, depois casei novamente e minha esposa virou uma segunda mãe para elas... A mãe mesmo nunca ligou, desapareceu por anos e agora voltou com um pedido de guarda das minhas filhas... eu não acreditei quando recebi a intimação. Nossa audiência ainda não aconteceu, mas já passamos por alguns atendimentos aqui... Na frente da psicóloga ela chora, se diz arrependida, mas eu sei que ela só está fazendo isso para receber o dinheiro porque até hoje não se interessou em estar com as filhas... Não sei se alguém ainda vai ouvir as crianças e o que o juiz vai decidir... A gente fica com medo né? Não sei se podem dar a guarda para ela só pelo fato de ser a mãe, mesmo tendo sumido esse tempo todo... Minha única preocupação nesse momento é não perder as minhas filhas."

O relato de Max Teixeira foi recebido como um verdadeiro contrassenso pelos demais participantes da oficina, na medida que geralmente era esperado o inverso: a ausência paterna, e não materna. Algumas mulheres ali presentes esboçaram comentários e reações de incredulidade e desprezo por essa figura capaz de abandonar suas filhas pequenas com o pai: "Isso não é mãe de verdade", alguém comentou obtendo a anuência dos demais. Dada a lógica hegemônica de uma subjetividade materna essencialmente caracterizada pela presença, cuidado e amor natural aos filhos, aquela narrativa lançou no grupo uma experiência abjeta, desprezível e que, como tal, não poderia ser reconhecida como parte do universo da "maternidade" por eles partilhada. Ao mesmo tempo, Max se tornou uma figura exemplar de um ponto que era muito reiterado nos discursos oficiais e que se configurou como uma das principais demandas e ações no âmbito da justiça humanizada: a valorização da presença e papel (sobretudo afetivo) dos homens-pais na criação dos filhos.

\section{O homem-pai tem a obrigação de dar afeto aos filhos}

A etnografia realizada Salazar (2020) apontou o caráter recente dos estudos que se propõem a (re)pensar a posição dos homens e os sentidos em torno das questões que envolvem noções de masculinidades e construções de gênero no âmbito das relações familiares. Nessa seara, surgem idealizações em torno da ideia de uma "paternidade ativa" (Salazar, 2020:69), sobretudo na classe média e nos discursos oficiais, mas que nem sempre se efetiva no cotidiano dos cuidados parentais e das vivências domésticas partilhados por homens e mulheres. Especialmente no campo de pesquisa do Cejusc, esses hiatos eram ainda mais acentuados em virtude do caráter conflituoso das relações estabelecidas nessas famílias e da judicialização dessas relações.

Destarte, notamos que tais famílias nem sempre estavam inseridas em uma lógica "psicologizada" em comparação à forma como produziam agenciamentos e operavam com a matriz da judicialização. 
Assim, a Oficina de Parentalidade constituía uma tecnologia fundamental para iniciação ou imersão daqueles sujeitos nesse universo de sentidos psicologizantes e judicializantes que fazem funcionar a dita "justiça humanizada", a qual curiosamente tinha uma dupla abordagem argumentativa: primeiro, de modo positivado, salientava-se a importância dos filhos contarem com a presença e o afeto dos homens-pais, que hoje, cada vez mais, participam e entendem que suas obrigações extrapolavam o sustento financeiro; segundo, por meio de um viés negativista, complementava-se a primeira ideia dando uma grande ênfase aos sentimentos e problemas comportamentais que os filhos poderiam apresentar em virtude da ausência do pai ocasionada pelos conflitos decorrentes do divórcio.

Foi interessante observar como a questão da presença paterna acionava tais retóricas entre os agentes estatais que, por sua vez, reproduziam (muitas vezes literalmente) falas similares àquela trazida na cartilha do CNJ:

[...] a ausência do relacionamento paterno, seja por divórcio, excesso de trabalho, descaso, etc., afeta drasticamente a vida dos filhos. As estatísticas mostram que o número de jovens que cometem delitos é maior entre os que foram criados longe do pai.

Os problemas que eles apresentam são:

- sentimento de rejeição;

- indisciplina;

- abandono dos estudos;

- mais abuso infantil;

- gravidez precoce;

- envolvimento com drogas;

- prostituição;

- problemas com as autoridades;

- participação em gangues de rua;

- violência;

- prática de crimes;

- suicídios;

- marginalização;

- emprego precário;

- pobreza;

- recorrência ao seguro-desemprego.

De acordo com a estatística mencionada, fica evidente a importância do pai na vida dos filhos, pois ele é a figura que representa a lei e impõe respeito. A atenção que o pai dedica ao filho desenvolve nele a autoestima e o amor-próprio. (CNJ, 2015a:80-81).

Discursos como estes evidenciam uma correlação causalista comumente estabelecida entre a ausência do pai e os problemas dos filhos, o que se dá por meio de uma leitura reducionista que se sustenta em supostos dados científicos e linguagem psicológica, dando sentido e funcionando como chave explicativa até mesmo para questões relacionadas à classe e às diferenças sociais. Dessa maneira, em concordância com Neyrand (2013), vemos que os discursos oficiais têm contribuído para reforçar 
a ideia de que os genitores devem sempre responder - ou ser culpabilizados - pelo comportamento de seus filhos, assim como de que depende exclusivamente destes a responsabilidade por se tornarem indivíduos autônomos, saudáveis e bem-sucedidos no exercício da cidadania e na garantia de seus direitos, referendando um viés individualista que desconsidera a organização social, histórica, política e cultural em que tais sujeitos estão inseridos.

Foi interessante perceber que esse era um dos momentos da oficina em que os participantes mais se envolviam, geralmente expressando concordância e preocupação com o que era dito, além de compartilharem exemplos e identificações com tais ideias, que eram, assim, tomadas como verdades, como vemos nos relatos a seguir:

"Eu tenho um primo que aconteceu isso aí: depois que o pai abandonou a família, ele primeiro começou a roubar dos comerciantes e sabe como é interior, rapidinho já tá todo mundo sabendo... Minha tia deu-lhe uma surra e o menino fugiu não sei pra onde. Depois de adulto já que fui ter notícias, soube que ele foi se envolvendo aí com outras coisas, até que foi preso. Tudo revolta do pai, eu vejo assim... Lá em casa foi parecido, quando meu pai morreu minha mãe deu um dobrado para criar os onze filhos sozinha... Como eu era o mais velho, precisei parar os estudos para trabalhar e ajudar a trazer comida pra casa. Não tenho vergonha não, pelo contrário, me orgulho porque só eu sei do que a gente passou..." - relata um dos pais presentes na Oficina.

"Meu problema, doutora, é que depois que o pai arrumou outra ele não quer saber da menina... Sei que hoje ela é muito novinha e não sente, mas não quero que depois minha filha fique com problema psicológico por ter crescido sem um pai. Ele anda dizendo que eu que estou impedindo ele de estar com a menina, mas sabe por que, doutora? Porque das últimas vezes ele pegou a menina e ficou enfurnado lá na casa da outra, fazendo sei lá o que... Ah, quando eu soube dei um jeito de descobrir o endereço e peguei minha filha de volta, disse que com aquela mulherzinha ela não ia ficar. Ele fala que eu sou louca, ciumenta, mas não é isso não. Quer ficar com a menina? Fica! Mas não na casa dela!" - compartilhou uma das mães.

E não foi só nas oficinas ou entre os pais e mães de classes populares que percebemos essa lógica. Nessa mesma semana, ouvimos reiteradamente o argumento de que os adolescentes estariam mais suscetíveis à delinquência devido às suas famílias desestruturadas. Essa fala repercutia e se repetia durante um debate acadêmico sobre atos infracionais e redução da maioridade penal com futuros operadores do Direito - acadêmicos na faixa etária de 18 a 25 anos, alguns deles estagiários do Cejusc que atuavam como conciliadores e expositores nas oficinas. Assim, observamos a concepção determinista de que "famílias desestruturadas" pelo conflito ou pela ausência paterna produzirão sujeitos predispostos à violência, como já identificara Wiggers (2010) em sua etnografia. Contudo, como a autora concluiu, tal argumento demonstra ser redundante e esvaziado de significado se não questionarmos quais bases definem "a estrutura e a desestrutura da família” e como as próprias famílias articulam (ou não) tais sentidos.

No decorrer da presente pesquisa, considerando as concepções e práticas que fazem a "humanização da Justiça”, pudemos perceber um sistema lógico primordial de cunho biopolítico que tem como elemento constituinte a intervenção sobre as sensibilidades e os afetos dos indivíduos, como 
já apontara Schuch (2009), em sua análise etnográfica da Justiça Restaurativa no Rio Grande do Sul, situado no mesmo movimento de harmonização das relações sociais e de reforma do judiciário. Além de conceber forte ênfase às emoções e serem "humanizados" na medida em que se propõem a ir além dos aspectos meramente legais e jurídicos, vale destacar aqui uma especificidade: os agentes estatais passam a incorporar orientações e alertas em relação aos supostos "danos psicológicos" ocasionados aos filhos, que se tornariam então vítimas dos conflitos familiares, sendo este o principal fator desestruturante da família:

\footnotetext{
"Nós estamos aqui porque queremos ajudar vocês, pais, a lidarem melhor com seus conflitos. Já falamos que o conflito é natural, não é um problema em si. A questão é a forma como a gente lida com eles! A gente sabe que não é fácil lidar com os sentimentos e decepções daquela relação que acabou, mas vocês são os adultos e os filhos não podem ser envolvidos nisso tudo. Eu, por exemplo, sou filha de pais separados, mas nem lembro direito do divórcio porque eu era bem novinha. Mas o pior de tudo era ver meus pais brigando ou falando mal um do outro, isso já foi até assunto na terapia! Por isso estamos aqui hoje falando para vocês nessa Oficina sobre a importância de vocês atentarem para as emoções de seus filhos e fazerem a sua parte, começando com pequenas atitudes e mudanças que ajudem a diminuir o nível do conflito de vocês. Com certeza vocês verão a diferença depois!" - Fala da expositora da Oficina de Parentalidade.
}

\footnotetext{
"Por mais que você esteja cansado e/ou estressado, por mais que seja difícil continuar se comunicando com o seu/sua ex, se esforce... Afinal, é o desenvolvimento saudável do seu filho que está em jogo!" (CNJ, 2015a:81).
}

Por meio de um viés individualizante e familiarista correlacionado às problemáticas do campo subjetivo e social, tal retórica se ancorava em uma forma de valorização da presença afetiva dos homens-pais fundamentada nos problemas ocasionados por sua ausência, concebida como potencialmente prejudicial e traumática para os filhos. Assim, por meio lógica da ameaça e do risco, eram enfatizadas a lista de consequências psicológicas que decorreriam dessa desestruturação da família: sentimentos de raiva, rejeição, comportamentos desajustados, ansiedade, depressão e até mesmo suicídio.

Foi interessante perceber, ainda, que tais enunciados eram expressos nas oficinas, corredores e audiências pelos conciliadores/mediadores de diferentes áreas, e não somente pelos estudantes e profissionais da Psicologia, tidos como especialistas em tal matéria, o que denota a importância desse teor psicologizante entre os agentes da justiça humanizada. Ante a tais enunciados, as famílias costumavam produzir identificações e sentidos para suas próprias vivências, referendando a necessidade de uma intervenção jurídica para resolução de seus conflitos.

\section{Considerações finais}

Ao analisar essa relação entre as famílias e o sistema de justiça, buscamos considerar os diferentes sensos, matizes, lógicas locais das famílias que emergiam nas cenas descritas. Observamos, assim, um 
movimento de captura e enquadre dos conflitos familiares em um sistema simbólico de referências legais, jurídicas e psicológicas que passam a explicar as dinâmicas familiares e as relações sociais em termos de riscos, danos, direitos, traumas, violências, dentre outras terminologias relacionadas às disciplinas do Direito e da Psicologia. Assim, em que pese a retórica oficial de um judiciário mais humanizado, com políticas voltadas a resolver consensualmente os conflitos familiares e estimular a autonomia dos sujeitos, verificamos a permanência da matriz da judicialização, incrementada por um discurso psicologizante, mesmo em meio às propostas de resolução dos conflitos e de harmonização das relações.

Em contato com os sujeitos e os agentes, pudemos notar que a relação entre as famílias e a justiça não estava posta em termos de problema ou solução, mas que coexistiam ambas as perspectivas. Em suma, a família como problema foi uma retórica constantemente empregada em situações em que os genitores, na perspectiva dos agentes, não se comunicavam bem, não resolviam seus conflitos de modo pacífico, não priorizavam os filhos, não cuidavam do bem-estar emocional das crianças, dentre outros pontos reiterados na oficina e intervenções de cunho educativo destinadas às famílias. Por sua vez, a ideia da família como solução se apresentava quando as partes eram reconhecidas como sujeitos racionais, abertos ao diálogo, inclinados ao acordo e dispostos a modificar seus modos de vida a partir das instruções recebidas pelos agentes da justiça humanizada - como se tais mudanças dependesse somente do acesso à informação e de sua aplicação.

Já o senso da justiça como problema ou solução era posto de diferentes maneiras, dependendo de quem falava: na retórica dos agentes estatais, a atuação autocompositiva, preventiva e humanizada do novo judiciário seria a solução adequada para os conflitos familiares, resolvendo de forma rápida, simples e eficaz questões que, de outro modo, levariam anos para terem um desfecho, inflacionando o sistema de justiça. Assim, a ideia da justiça como problema era empregada nos discursos oficiais para se referir às situações em que o conflito não era resolvido consensualmente, necessitando da decisão judicial, o que muitas vezes era enunciado como uma "decisão imposta” para as famílias. Por outro lado, muitas vezes essa era justamente a solução esperada pelos sujeitos que buscavam o Cejusc: não necessariamente a resolução do conflito, a melhoria do diálogo e a transformação daquela relação, mas simplesmente alguém autorizado (fosse o juiz, o mediador, a psicóloga ou outro "doutor/doutora") a impor uma regra, uma recompensa, um direito ou mesmo uma pena para a outra parte, obrigando-a a agir reparando os danos e transtornos gerados pelo conflito.

As lógicas locais estavam postas e quase sempre coincidiam com a crença coletiva partilhada de que, naquele espaço de justiça humanizada, as famílias adquiririam - tanto rapidamente quanto magicamente - melhores ferramentas para mudarem suas atitudes, resolverem seus conflitos, contornarem seus problemas e, assim, saírem melhores do que entraram. Ademais, pudemos perceber tanto a expectativa depositada na Justiça quanto o intento comum entre os interlocutores de modificação dos sentimentos e das condutas conflituosas, as quais eram concebidas como lesivas ao bem-estar, à felicidade e ao desenvolvimento saudável de seus filhos.

Assim, foi possível notar que a justiça humanizada conjuga as lógicas psicologizantes e judicializantes por meio dessa modalidade discursiva alarmante e acusatória que coloca os pais, suas intenções e comportamentos em cheque, de maneira que "a família torna-se tanto o lugar de suspeita, quanto si- 
multaneamente o objeto e o instrumento de intervenção" (Schuch, 2013:312). Com efeito, justifica-se o cunho biopolítico das intervenções e tecnologias que visam regular as vivências conflituosas, os modos de ser/funcionar das famílias, o exercício da parentalidade, etc.; tecnologias estas que se ancoram em uma positivação das relações familiares e afetivas, de modo a negar/evitar sua dimensão conflituosa que supostamente traria prejuízo ao bem-estar e à felicidade dos filhos.

Portanto, podemos afirmar que hoje se consolidou a ênfase aos componentes afetivos, emocionais, subjetivos e psicológicos nos discursos e práticas dos agentes e das próprias famílias, especialmente quando se fala dos métodos adequados de resolução de conflitos. Em nome da transformação dos comportamentos e emoções, da harmonização das relações e da redução dos conflitos, vemos a legitimação de biopolíticas que, tais como as oficinas etnografadas, operam e fazem circular sentidos e significados construídos socialmente acerca das famílias, de seus modos de funcionar e das posições ocupadas por homens e mulheres no âmbito dessas relações. Dado o cunho moral, normativo e reducionista de tais construções, este texto buscou problematizar como esse universo de sentidos é (re)produzido e operado cotidianamente pelas famílias e pelas instituições jurídicas, atualizando as formas de judicialização das famílias e das relações sociais.

Camilla Felix Barbosa de Oliveira é doutora em Antropologia Social pela Universidade Federal do Amazonas (UFAM) e psicóloga.

Raquel Wiggers é doutora em Ciências Sociais pela Universidade Estadual de Campinas e professora do Departamento de Antropologia e do Programa de Pós-Graduação em Antropologia Social da Universidade Federal do Amazonas (UFAM). Na ocasião da pesquisa, coordenou o projeto de pesquisa "Familias e moralidades: modelos de organização familiar e de gênero na Amazônia”, com financiamento do CNPq.

\section{REFERÊNCIAS}

CNJ. (s/d.) Portal de Conciliação e Mediação. Perguntas Frequentes. Recuperado de https://www.cnj. jus.br/programas-e-acoes/conciliacao-e-mediacao/perguntas-frequentes-7/

CNJ. (2014). Recomendação CNJ n50/2014. Brasília.

CNJ. (2015a). Cartilha do divórcio para os pais. Brasília. 
CNJ. (2015b). Conheça a Lei n. 5.478/1968, que dispõe sobre ação de alimentos. 23 dez. Facebook. https://pt-br.facebook.com/cnj.oficial/photos/conhe\%C3\%A7a-a-lei-n-54781968-que-disp\%C3\%B5e-sobre-a\%C3\%A7\%C3\%A3o-de-alimentos-httpbitly12mapqr-e-t/1000385873367506/

CNJ. (2019). Pensão alimentícia atrasada? 30 jan. Facebook. https://pt-br.facebook.com/cnj.oficial/ photos/a.191159914290110/2533550006717744/?type=3\&theater

CNJ. (2020). Regulamento do Sistema de Ações de Capacitação e do Banco de Dados da Política de Tratamento Adequado de Conflitos. Brasília: ConciliaJud.

Fonseca, C. (2002). Mãe é uma só? Reflexões em torno de alguns casos brasileiros. Psicologia USP, 13(2), 49-68. https://doi.org/10.1590/S0103-65642002000200005

Fonseca, C. (2011). As novas tecnologias legais na produção da vida familiar: Antropologia, direito e subjetividades. Civitas - Revista de Ciências Sociais, 11(1), 8-23. https://doi.org/10.15448/19847289.2011.1.9188

Foucault, M. (2005). Em defesa da sociedade: Curso no Collège de France (1975-1976). São Paulo: Martins Fontes.

Lima, N. S. (2018). Entre mundos de sentido: violência sexual, familia e parentesco a partir do grupo da Autores em Manaus/AM (Dissertação de Mestrado). Programa de Pós-graduação em Antropologia Social, Universidade Federal do Amazonas, Manaus.

Neyrand, G. (2013). Soutien à la parentalité et contrôle social. Bruxelles: Yapaka.

Oliveira, C., \& Brito, L. M. T. (2016) Humanização da Justiça ou judicialização do humano? Psicologia clinica, 28(2), 149-172. https://www.redalyc.org/articulo.oa?id=291052545009

Oliveira, C. (2020). Entre conflitos familiares e resoluçôes consensuais: a judicialização em tempos de bumanização da Justiça (Tese de Doutorado). Programa de Pós-graduação em Antropologia Social, Universidade Federal do Amazonas, Manaus.

Rifiotis, T. (2007). Direitos Humanos: Sujeito de Direitos e Direitos dos Sujeitos. In R. M. G. Silveira et al. (orgs.). Educação em Direitos Humanos: Fundamentos Teórico-Metodológicos. João Pessoa: Editora Universitária.

Rifiotis, T. (2014). Judicialização dos direitos humanos, lutas por reconhecimento e políticas públicas no Brasil: configurações de sujeito. Revista de Antropologia, 57(1), 119-144. https://www.revistas. usp.br/ra/article/view/87755 
Salazar, V. (2020). Etnografia feminista da maternidade: as experiências de mulheres-mães de camadas médias brasileiras e venezuelanas compartilhadas nas redes sociais (Dissertação de Mestrado). Programa de Pós-graduação em Antropologia Social, Universidade Federal do Amazonas, Manaus.

Sarti, C. (1992). Contribuições da antropologia para o estudo da família. Psicologia USP, 3(1-2), 6976. https://www.revistas.usp.br/psicousp/article/view/34459

Schuch, P. (2009). Tecnologias da não-violência e modernização da justiça no Brasil. Civitas - Revista de Ciências Sociais, 8(3), 498-520. https://doi.org/10.15448/1984-7289.2008.3.4872

Schuch, P. (2012). Família no plural: Considerações antropológicas sobre família e parentesco (à luz dos seus confrontos de significados num órgão da justiça juvenil). Apresentação oral.

Schuch, P. (2013). Como a família funciona em políticas de intervenção social? Civitas - Revista de Ciências Sociais, 13(2), 309-325. https://doi.org/10.15448/1984-7289.2013.2.15483

Tribunal de Justiça da Bahia (2013). Cartilha da Família - Não à alienação parental. Bahia: [s.i.]

Velho, G. (2010). A Utopia Urbana: um estudo de antropologia social. Rio de Janeiro: Jorge Zahar Editor.

Werneck Vianna, L. (1999). A Judicialização da Política e das relaçôes sociais no Brasil. Rio de Janeiro: Ed. Renavan.

Wiggers, R. (2010) Familia em Conflito: violência, espaço doméstico e categorias de parentesco em grupos populares de Florianópolis (Dissertação de Mestrado). Programa de Pós-Graduação em Antropologia Social, Universidade Federal de Santa Catarina, Florianópolis. 


\title{
(DIS)SENSOS E LÓGICAS DAS FAMÍLIAS EM UM CENTRO JUDICIÁRIO DE SOLU- ÇÃo de CONFLITOS E CIDAdANIA
}

Resumo: O presente artigo se propõe a analisar as construções discursivas e as lógicas locais das famílias que demandam os serviços do sistema de Justiça amazonense. Por meio de etnografia realizada nas Oficinas de Divórcio e Parentalidade, voltamos nosso olhar para o conjunto de (dis)sensos sobre as famílias que caracterizam tais políticas conciliatórias. Observamos, então, o movimento de captura dos conflitos familiares em um sistema simbólico de referências jurídicas e psicológicas que explicam tais dinâmicas em termos de riscos, danos, traumas, dentre outras terminologias do Direito e da Psicologia. Assim, em que pese a retórica oficial de um judiciário mais humanizado, voltado a resolver consensualmente os conflitos e a estimular a autonomia dos sujeitos, verificamos a permanência da matriz da judicialização incrementada por um discurso psicologizante que circula sentidos acerca dos modos de ser das famílias e das posições ocupadas por homens e mulheres nessas relações.

Palavras-chave: justiça; conflitos familiares; judicialização; psicologização; mediação.

\section{(DIS)SENSES AND LOGICS OF THE FAMILIES IN A JUDICIAL CENTER FOR CON- FLICT RESOLUTION AND CITIZENSHIP}

\begin{abstract}
This article aims to analyze the discursive constructions and the local logic of the families that demand the services of the justice system in Amazon, Brazil. Through ethnography carried out in the Divorce and Parenting Workshops, we turn our attention to the set of (dis)senses about families that characterize such conciliatory policies. We observed, then, the movement to capturing family conflicts in a symbolic system of legal and psychological references that explain such dynamics in terms of risks, damages, traumas, among other terminologies of Law and Psychology. Thus, despite the official rhetoric of a more humanized judiciary, aimed at consensually resolving conflicts and stimulating the autonomy of the subjects, we verify the permanence of the judicialization matrix increased by a psychologizing discourse that circulates meanings about the ways of being families and the positions occupied by men and women in these relationships.
\end{abstract}

Keywords: justice; family conflicts; judicialization; psychologization; mediation.

RECEBIDO: $20 / 11 / 2020$

ACEITO: $19 / 07 / 2021$ 